

\title{
A Pavilion in the Danish forest by Vilhelm Wohlert; Tradition and Modernity
}

\author{
Carmen García Sánchez
}

\begin{abstract}
Danish architect Vilhelm Wohlert (1920-2007), after a stay as a guest teacher at Berkeley University, designs his first building. Created in a period of a flourishing architecture, it achieves a balance between Danish tradition and modernity, where international references -American architecture and Japanese tradition- are significant. Its ability to fit into the circumstances, sets a model for the buildings of the future. There is a dialogue with the surrounding nature, her careful observation; establishing a great connection, where the Danish attitude towards her is not a domination. The architect knows the material and uses it in harmony with its essence. The study suggests that the vernacular may be a process that evolves and transforms over time involving a significant level of modernity, and that a look at it could be an answer to prevent the loss the identity of architecture.
\end{abstract}

Key words: Vilhelm Wohlert, Danish tradition, Japanese tradition, nature, material, vernacular.

\section{Un Pabellón en el bosque danés por Vilhelm Wohlert; Tradición y Modernidad}

Resumen: El arquitecto danés Vilhelm Wohlert (1920-2007), tras una estancia como profesor invitado en la Universidad de Berkeley, proyecta su primer edificio. Construido en un periodo de florecimiento arquitectónico, logra el equilibrio entre la tradición danesa y la modernidad, donde las referencias internacionales -la arquitectura americana y tradición japonesa- serán trascendentales. Su capacidad para adaptarse a las circunstancias, lo convierte en un modelo para los edificios del futuro. Hay un diálogo con la naturaleza circundante, su atenta observación; estableciéndose una gran conexión, donde la actitud danesa hacia ella no es de dominación. El arquitecto conoce el material y lo utiliza en armonía con su esencia. El estudio sugiere que lo vernáculo puede ser un proceso que evoluciona y se transforma con el tiempo, implicando un nivel significativo de modernidad, y que una mirada a ello puede ser una respuesta para prevenir la pérdida de identidad de la arquitectura.

Palabras clave: Vilhelm Wohlert, tradición danesa, tradición japonesa, naturaleza, material, vernáculo.

\section{Introduction}

In Denmark, around 1950, after the second war and a period being isolated, the economy begins to grow again, giving rise to a new era of architecture, the so called "Golden Age of Danish Modern Architecture". Young Danish architects experiment with ideas of an international origin, encouraged by different circumstances. They find the best field of rehearsal to be the domestic space.

The third generation of architecture, so named by Sigfried Giedion (1888-1968), developed in Denmark, shares values with past buildings, tracing its roots to the Danish tradition: deeply connected to craftsmen's knowledge, the skilled use of materials and the wisdom of anonymous buildings. It brings together all artistic disciplines; advances and regenerates itself from the already known through the assimilation of international impulses; and develops an architecture which aim is to: renew itself preventing the loss of authenticity maintaining its Danish identity and know "the truth" and "the original essence" of the architectural act.

The Danish architect Vilhelm Wohlert (1920-2007) after a brief stay as a guest teacher at Berkeley University in California, comes back to Denmark to establish his office. 


\section{Aim}

The aim of the investigation is to unveil some keys to Danish modernity in the field of architecture, through his earliest construction, in which the Japanese tradition took a special place; to identify, reveal and recover some of its teachings, which are considered prevailing today.

\section{Methodology}

The research analyses backgrounds, figures and buildings relevant to Danish tradition; and some examples of Japanese traditional and American architecture. Affinities and shared sensibilities are detected.

\section{Development}

The modest guesthouse that Wohlert built in 1957 for Niels Bohr, Nobel Prize in Physics in 1922, was his first building. Created in a period of flourishing architectural, it roots in the Danish tradition, where the principles of the Skønvirke are present. It achieves a balance between the vernacular tradition and modernity, where international references -American architecture and Japanese tradition- will be significant. [figure 1] [figure 2]

Professor Bohr commissions Wohlert to renovate his summer house and a new wing for guests. The plot was integrated in a remote virgin forest in the northern of Sjælland. The architect suggests construct a separate guesthouse to preserve the integrity of the existing house and to have other advantages. Bohr accepts the proposal, stipulating that the building should be inexpensive and finished by the end of the following summer. (Nyborg and Wohlert 1987: 9).

The architect designs a freestanding container that preserves the open area around it. His task will be perceiving the vocation of the place, respecting its identity despite the changes; to create a new place where architecture and nature will coexist, the "genius loci" will endure. The visitor is readied for the experience of the architecture, where the manner of approaching the building becomes significant. The impression is slowed, to liberate the individual of mental assumptions and to reach both an appropriate mood and a high level of intimacy.

He presents his building as a body of pure lines and characteristic abstraction. It shows its own entity, alluding the modern concept of pavilion. Its light enclosure and the way it can be unfolded, confer the sense of being a piece of furniture, a cabinetmaker's delicate work. It seems deceitfully simple; a timber clad box that seems to float over the green meadow, opens to the southwest and closes to the northeast.

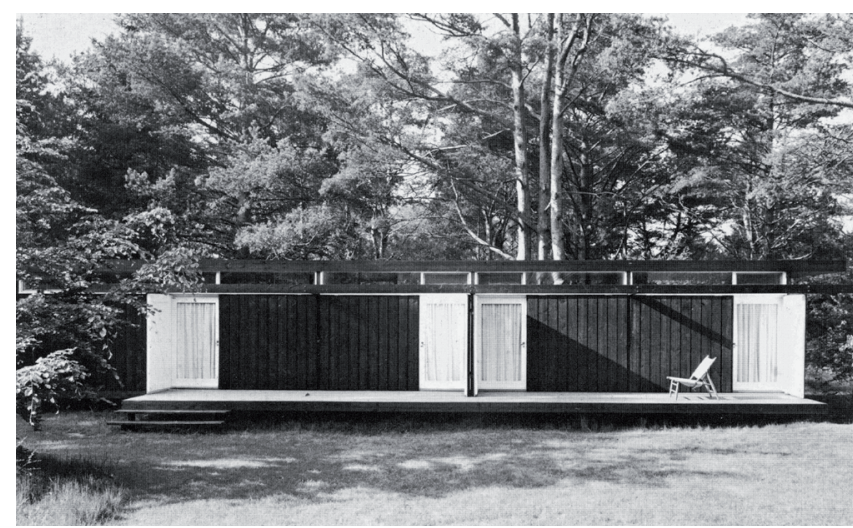

Figure 1.- Niels Bohr's guesthouse. Photographer Jesper Høm. Jesper Høm's collection. Sheridan, M., (2014). Landmarks, the Modern House in Denmark. Ostfildern: Hatje Cantz. p.56.

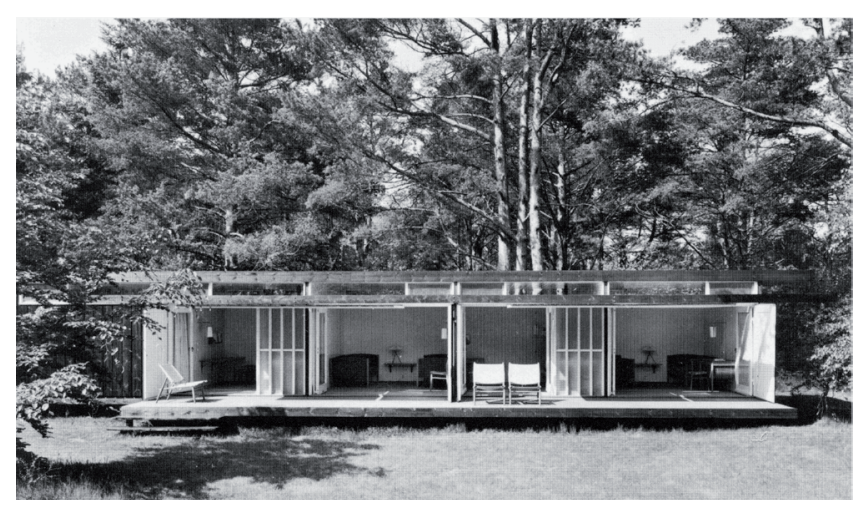

Figure 2.- Photographer Jesper Høm. Jesper Høm's collection. Sheridan, M. (2014). Landmarks, the Modern House in Denmark. Ostfildern: Hatje Cantz, p.56.

\section{Danish Tradition}

Wohlert knew traditional Danish architecture's bases by his mentor Kaare Klint (1888-1954). His father, the architect and teacher Jensen Klint (1853-1930), a key figure in the evolution of modern Denmark, understood that the architect's task was one less of creation and more of construction. He promoted respect for the context, the clear proportions, the use of traditional craftsmanship and material of the place, the importance of details and a good use of the effect of textures. He was inspired by Mathematics and nature's rules of growth, which he considered the latter key to recovering the form. He stated:

"Let as cultivate, the object, the surface, the materia, in keeping with its essence and the requirements of the day, and never resort to copying old styles, but through a thorough cultivation and acquisition of the unfailing taste and dignified approach to style of ages past, pursue our personal style, with the aim of creating cozy, beautiful, and magnificent surroundings for modern man's life and activities" (quoted by Jensen 2009: 37).

Kaare Klint creator of the cabinetmakers school, in 
connection with the School of Architecture within the Academy in Copenhagen, introduced his father's teachings that were incorporated into the pedagogy of the Academy, the so called "School of Klint"; where Vilhelm Wohlert and others studied. The sensibility to the landscape, interest in topography, material and climate; an architecture begotten in part by nature; a feeling for rooted vernacular architecture; are concepts that were impressed by Jensen Klint on this generation.

Church of Grundtvig (1921-1940), J. Klint's masterpiece, was fundamental point of reference for the precision of its craftsmanship and its use of uncut fair-faced brickwork throughout (Frampton and Cava 1995: 250). It clearly embodies the resurgence of Danish tradition of brick. [figure 3] It is based on the repetition of a single material, yellowish brick, the same for all; floors, walls, vaults, stairs, etc ... The exclusive use of a single modular material is also a feature of Niels Bohr's guesthouse, built entirely of wood and rested on three concrete walls.

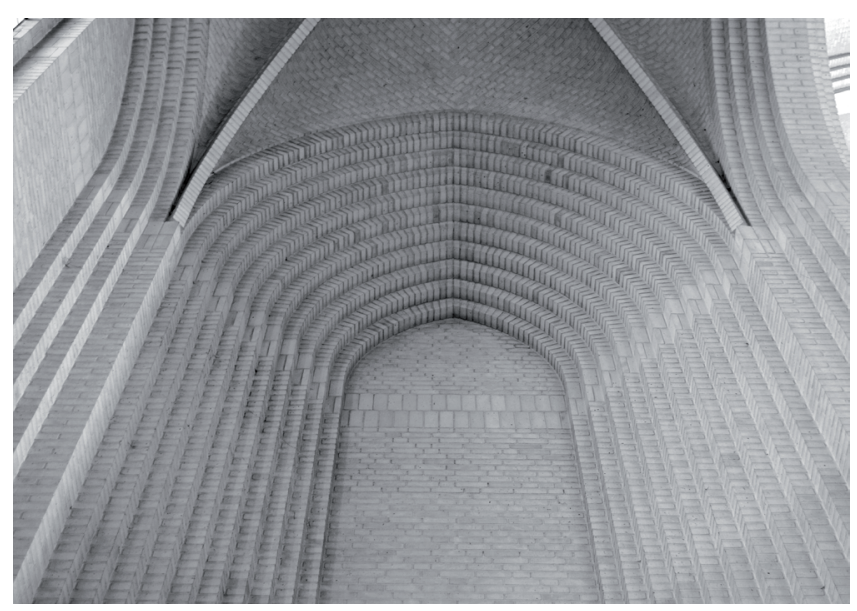

Figure 3.- Grundtvig church (1921-1940), by Jensen Klint. Photographer Carmen García Sánchez Copenhagen, December 2016.

The Danish architect and teacher, Carl Petersen (18741923), and his three lectures, keys in the evolution of Denmark towards the Modernity, are also present in the pavilion. He was interested in East Asian crafts, techniques and surface treatments of materials. In "Textures" (1919) (Paavilainen et al 1982: 35-38), he says that each material should show the suitable texture, which does not mask or destroy its essence. Petersen refers to wood as an essential material, the appearance of its surface is more appealing to the Danes for being familiar. The materials are no longer used for their historical value or refinement, but according to their surroundings, their color, their preparation, surface treatment or other attributes. In "Contrasts" (1920) (Paavilainen et al 1982: 45-48), he defends the moulding as a fundamental element in the art of contrast. He refers to the scale of the building, the logic of the proportion, of its components and its relationship with the environment where it is located. The preference for pure and bright colors, stemmed directly from "Golden Age" of Danish art and exemplified by Thorvaldsen's Museum, are expressed by him in "Colors" (1923-24). Petersen had studied the effects sought by Nordic Neoclassicism's architects, trying to integrate all the arts, handicrafts, references from other cultures and ages. Wohlert embodies the evolution of this tradition and its renewal, based on the adaptation of foreign influences.

Observing the guesthouse, the simplicity and the modular framework of vernacular building tradition of timber, from Danish farmhouses or fisherman's cottages, are recognized. Vernacular models, which constructive form is characterized by the clear structural order and precise measurements, are marked by the modular logic and its good proportion.

Kay Fisker (1893-1965), and his partner Aage Rafn (18901953) designed some train stations in the island of Bornholm (1915); Fisker designed some summer houses with rectangular planshape, and a single bay (19161918). [figure 4] These projects evoke the "Long Danish houses" and typify Danish Functionalism. They are a source of inspiration for some architects' projects of the third generation: as a summer shelter by Jørn Utzon (1918-2008), built in Ålsgårde (1939); some single-family houses by Arne Jacobsen (1902-1971); or the guesthouse by Wohlert. The Viking postulates reappear with the Functionalism. The elegant Viking ships, symbol of Danish culture, were the most precious jewels of its civilization (800-1050 a.c.). They, entirely built with wood, displayed the advanced stage of craftsmanship reached at that time. Their winter camps fortress, Dannevirke, surprise by their typological regularity of the buildings and the accuracy of the construction system used. Their buildings, the "Long Danish houses", like their ships, had very precise measurements.



Figure 4.- Proposal for summer house by Kay Fisker (1919-1923), in Hareskovby. Original drawing property of Royal Danish LibraryDanish National Art Library, Collection of Architectural Drawings. 


\section{American references}

The connection with American architecture is crucial. However the great masters, the connection with those of the Bahia Area and their work stands out. Wohlert was very impressed by "(...) their close association with their luxuriant nature around them which enhanced them and made them significant" (quoted by Pardey 2007: 16). His project draws a line with the wooden buildings of the San Francisco and the American tradition of the timber houses. [figure 5] His commitment to users' comfort is shown since the beginning of the project. It has been thought for human activity. It is designed for the experience of its interior, is carefully designed and possesses a meaningful relationship with the surrounding exterior. American references also come from the architecture of Marcel Breuer (1902-1981). (Garcia 2015: 73)

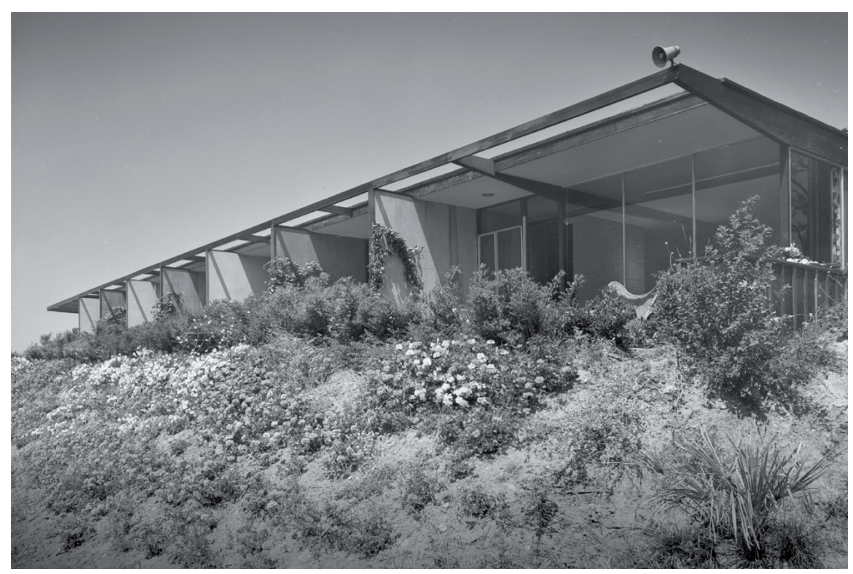

Figure 5.- House Apartments (Malibu, Calif.), by Richard Neutra (1949) Photographer Julius Shulman. Archives of J. Paul Getty Trust. Getty Research Institute, Los Angeles (2004.R.10, Job 283.10).

\section{Japanese Tradition}

In the investigation, beautiful parallelisms to traditional Japanese architecture, designed for the perception of all the senses, are established. Wohlert had never been to Japan, but he knew its culture through different references: a real Japanese tea pavilion the "Zui Ki Tei", rebuilt in the Etnografiska Museet of Stockholm (1935), and the interior of a Japanese house exhibited at the showroom "H55" Helsingborg (1955), that he could have visited; and indirectly by relevant books like: "Das Japanische Wohnhaus" (1935) and "Japanische Architektur" (1952) both by Tetsuro Yoshida, "Des japanische haus und sein leben" (1936) by Bruno Taut; and through the work of some American architects, such as Frank Lloyd Wright (1867-1959) or Charles and Henry Greene (1868-1957, 1870-1954). The inspiration of the East will be a constant in Wohlert's trajectory. (Balslev 2004: 46, 61, 62).
He uses a module 1:2 that orders the plan of the building. [figure 6] Its proportion and dimension, are based on the measurements of the standard mat that orders the Japanese traditional house. It comes from the standardization of timber construction, governed by the desire of working with whole lengths and measures. Everything fits like a whole, without a single cut board and any waste of material, providing economy and unity. It is "mounted" architecture which has previously been studied. The modulated order, without wasting material, and the design adjusted to the human scale, come from teachings by Kaare Klint and Japanese culture; bringing out the great unity of the building. It is a moderate architecture, that lacks exaggerations, where avoid the striking is a sign of strength. Scale is valued. It conveys serenity and beauty. A beauty that is also based on its utility, as the Danish term "brugkunst"-the art of creating an object- expresses. On the other hand, the building evokes to Japanese traditional architecture that is raised off the floor due to the rain of the wet season. It, built with wood, is a type of construction easy to be ventilated, no permanent, simple and inexpensive. Some elements of the guesthouse remind us of them: the terrace evokes to the porch or engawa; moving parts such as the large shutters are inspired by the Japanese shitomido, wood doors that swing out and up; folding doors recall biombos... [figure 7]

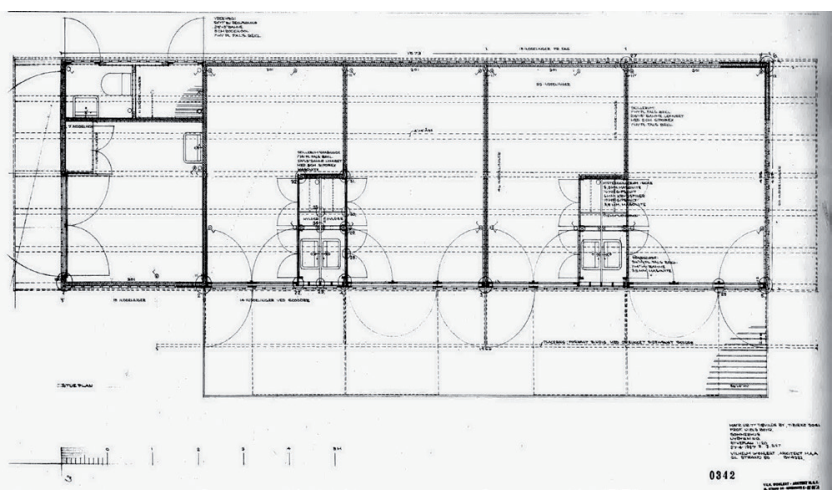

Figure 6.- Guesthouse plan, drawing by Vilhelm Wohlert. PARDEY, J., (2007). Louisiana and Beyond: The Work of Vilhelm Wohlert. Hellerup (Denmark). Blondal. p.26.

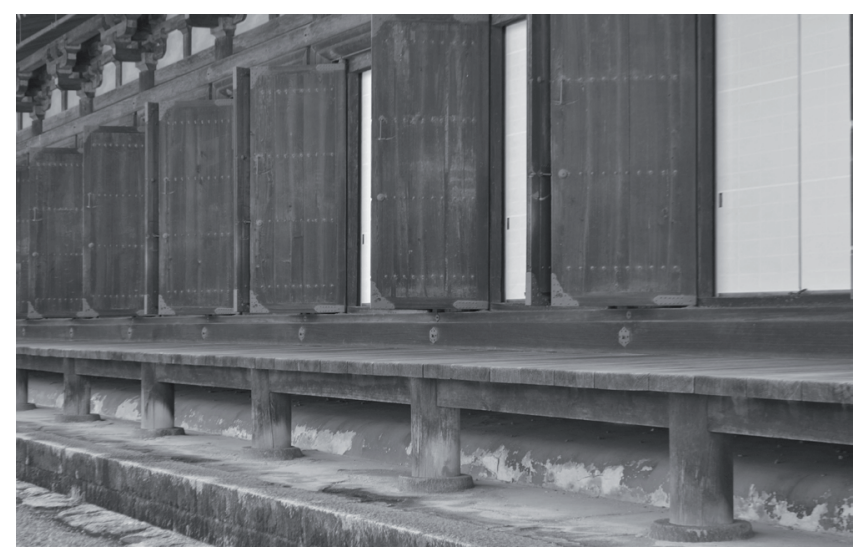

Figure 7.- Sanjūsangen-dō hall, Kyoto Prefecture (1164). Photographer Carmen García Sánchez April 2016. 
The abstract wood building, conceived as a seasonal place, can be closed in the cold Danish winters, and be partially opened during the warmer seasons. It is an organic manifestation, a living being, which has the sensitive capacity for movement through the variable positioning of its layers and to change according to variations that take place with the passing of time or with the seasons. When the enigmatic box is open, it gives rise to revelations: the space extends towards the forest through its open enclosure; there is a great connection to the surrounding nature, which presence within the interior is very intense, as of it, her changes are ever-present. "It pays tribute to transformation, associated to the change between seasons" (Garcia, in press). A sensibility common to Japanese culture is detected, where nature and life are united.

Per Olaf Fjeld stated: "Day light is probably our most profound connection to nature and life". (Garnert et al 2011: 21) According to this, in the association between nature and the interior space, day light will play a transcendental role. The Nordic light, much dimmer and absence, constantly changes throughout the year; marks life, experience of the architectural spaces and the people's mood (Garnert et al 2011). It, that gives everything its presence in the words of Louis Khan, interferes in the impression of surfaces by its incidence, that manifest their spatial value through their textures. Wohlert uses it wisely.

When the solid shutters and doors fold, air circulation creates a sense of freedom, and an architecture of horizontal spatial flow is set, associated with nature constant flux. The horizontal plane is dominant, there is a strong connection with the land; both circumstances offer order and security. The terrace is a delicate platform, that has a dual character, it is an extension of the house or an extension of the forest, a transitory space, like a Japanese engawa. But it also has a contemplative function, typical of the Eastern tradition, becoming an exciting place of exchange between nature and spirituality. On the other hand, it reminds the Japanese nō, or stage, where life takes place.

The pavilion could be seen as ikebana, the Japanese art of flowers, "the art of space", that is "rigorously constructed", something alive, which great emptiness projects tension and power; where is produced a circulation of air between its components (Barthes 1991: 44 cit. by Garcia, in press). Ikebana, an art that "gives life to flowers" -which true meaning is a positive interaction between the human being and nature, where there is a careful observation and dialogue with her and not a domination- shares characteristics with the guesthouse: the third dimension, the lack of symmetry reaching balance, the emotion of both the material and its texture... The asymmetrical concept that had already emerged at the Stockholm Universal Exhibition (1930), is also present in other Japanese references; like the shelves chigaidana, which suggest a changing world, where the hidden depths and potential extensions are possible.
The material inspires the architect according to its physical qualities: such as its surface texture, firmness, smoothness, density or structural capacity. Wohlert deepens into its essence, emotional expression and symbolic content, as in the Japanese culture; reaching certain intimacy with it. He knows the material and uses it in relation to what surrounds it. Its relationship with the environment and striking harmonious oneness, shows a great beauty. But it is not only a visual harmony, it is also haptic; were the power of the finish and its emotional character play an important role. The natural material, the wood, is not beautiful because it looks delightful, but because it has aged and lived an important experience, it is close to an end, and therefore, next to merge with death. In this way, when the construction disappears, a connection with both death and ecology could be established. The project alludes to the modern Japanese idea that the house is transitory. This is expressed by the hyosatsu, sign on the facade of traditional houses, finished by the word "Gü" (temporary residence) (Nakagawa 2016: 251) or the shrine buildings at Gekū and Naikū, in Ise Grand Shrine, rebuilt every 20 years as a part of the Shinto belief of the death and renewal of nature and the impermanence of all things, wabi-sabi. This transitory feeling was explained by Jørn Utzon who stated:

"Well, we are not...really interested in how things will be in 25 years, whatever we build. Actually, what we are interested in is that if in 2000 years some people dig down, they will find something from a period with a certain strength and purity belonging to that period" (quoted by Frampton and Cava 1995: 289).

It could be said that the spirit of poverty as the basis of aesthetics, eliminating the superfluous that distracts from the experience of the place, and the presentation of material's inherent appearance, are common to Nipponese culture. Wohlert creates an elegant balance between rustic and refined, by a careful design and attention to detail and jointing. He draws plans and sections scale 1:1, illustrating each board and part of the building. The project, developed at all scales, forms a global work. [figure 8]

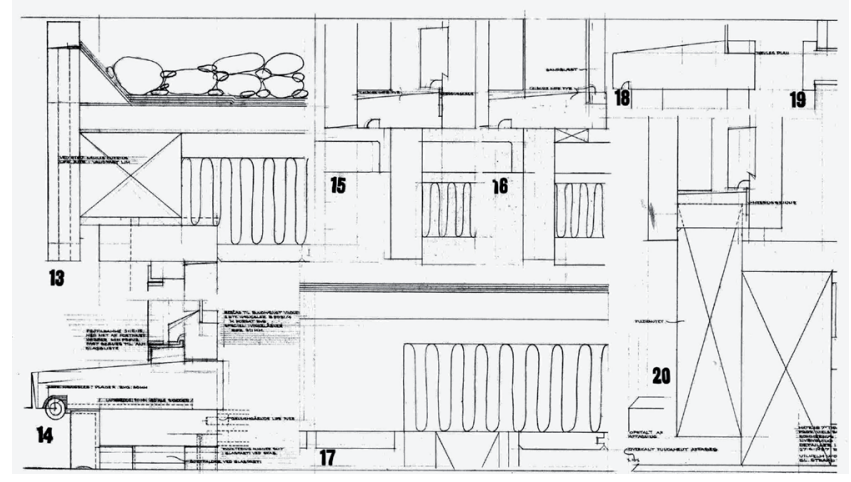

Figure 8.- Guesthouse constructive details, drawing by Vilhelm Wohlert. PARDEY, J., (2007). Louisiana and Beyond: The Work of Vilhelm Wohlert. Hellerup (Denmark). Blondal. p.27.. 
Professor Bohr hosted guests and relatives in the building until his death. Today it is protected by the Danish Agency for Culture to be preserved, has its original function and belongs to his descendants, that maintain it with devotion.

\section{Conclusions}

The guesthouse shows the scenery where life takes place, which remains exposed to the actions of the natural environment. Its architecture, surrounding nature, and life, all come together in harmony being gentle to human beings. It is a lesson entirely of the present.

"Respect for material" and "honest construction", two concepts handed down to Danish architects through the ages, are invaluable rules today. As the Danish architect Jørn Utzon pointed in 1948, the architect must become one with his materials and be able to form and use them in harmony with their nature. The time we live in, is different from any previous one, but the essence of architecture, is the same.

The pavilion represents a modern version of vernacular architecture, where the ability of the building to fit to the circumstances, like weather changes, seasons or guest's preferences, makes it a model for the buildings of the future. The tradition can be seen as creative processes through which architects, interpret past knowledge and experiences to face the demands and challenges of today. On the other hand, it could be said that the look at the vernacular -an anonymous architecture which is concerned with the historic, rural and preindustrial heritage of construction- may be an answer to avoid the feared loss of identity brought about by the contemporary process of modernization and its universalization. Rather than being a nostalgic reflection upon the past, it may be a process that evolves and transforms over time, involving a significant level of modernity; and play a meaningful role as a provider of settlements and buildings more sustainable for the time to come, as a response to the pursuit of the "truth" and the "original essence" of the architectural act.

\section{Bibliography}

ASQUITH, L., et al. (2006). Vernacular Architecture in the 21st Century: Theory, Education and Practice. New York: Taylor \& Francis Routledge.

BALLANTYNE, A. and SMITH, C. (2012). Architecture in the Space of Flows. London: Routledge.

BALSLEV, L. (2004). Den Sidste Guldalder - Danmark i 1950'Erne. København, Arkitektens Forlag.

BARDí I MILÁ, B., et al. (2010). Nórdicos. DPA, n²6. Barcelona: DPA: Documents de Projectes d'Arquitectura E.T.S.A.B. Universidad Politécnica Cataluña ed.
BARTHES, R. (1991). El Imperio De Los Signos. Madrid: Mondadori España.

FABER, T. (1978). A History of Danish Architecture. 2. København: Det Danske Selskab.

FISKER, K., et al. (1927). Modern Danish Architecture. London: Ernest Benn Limited.

FRAMPTON, K. and CAVA, J., (1995). Studies in Tectonic Culture: The Poetics of Construction in Nineteenth and Twentieth Century Architecture. Cambridge, Massachusetts: MIT Press.

GARCIA, C. (2015). “El Pabellón Niels Bohr. Tradición Danesa y Modernidad". Rita n 04. Madrid: Redfundamentos, S.L. ed., 64-75.

GARCIA, C. (2015). "1950 En torno al Museo Louisiana 1970". Phd. Thesis. Universidad Politécnica de Madrid. E.T.S.A.M., Departamento de Proyectos Arquitectónicos, Madrid.

GARCIA, C. "Niels Bohr's guesthouse, tradition and modernity in Denmark". MNCARS (in press).

GARNERT, J., et al. (2011) Nordic Light, Interpretations in Architecture. Stenløse: Dansk Center for Lys.

GIEDION, S. and ESPAÑA MINISTERIO DE VIVIENDA (1966). Jørn Utzon y la Tercera Generación. Madrid: Ministerio de la Vivienda, Secretaría General Técnica.

JENSEN, T.B. (2009). P.V. Jensen-Klint: The Headstrong Master Builder. Danmark: The Royal Danish Academy of Fine Arts, School of Architecture Publishers ed.

KUMA, K., (2010). Kyokai: A Japanese Technique for Articulating Space. Japan: Tankosha Publishing Co ed.

NORBERG-SCHULZ, C. (1980). Genius Loci, Towards a Phenomenology of Architecture. London/New York: Academy Editions/Rizzoli.

NAKAGAWA, T. (2016). La Casa Japonesa: Espacio, Memoria y Lenguaje. Universidad Politécnica de Madrid. E.T.S.A.M. Departamento de Composición Arquitectónica. Barcelona: Reverté.

NYBORG, A. and WOHLERT, V. (1987). Selections. København: Anders Nyborg Private Edition.

PAAVILAINEN, S., et al. (1982). Nordisk Klassicism, 1910-1930-Nordic Classicism, 1910-1930. Helsingfors: Finlands Arkitekturmuseum, cop.

PARDEY, J. (2007). Louisiana and Beyond: The Work of Vilhelm Wohlert. Hellerup: Blondal.

PORPHYRIOS, D. (1977). “Casas Reversibles: Arquitectura Danesa y Sueca 1905-1930". Erik Gunnar Asplund, 1990. Barcelona: Stylos ed., vol. 3, pp. 49-63 
SHERIDAN, M. (2014). Landmarks, the Modern House in Denmark.

Ostfildern: Hatje Cantz.

TAUT, B. (2007). La Casa y La Vida Japonesas. Barcelona: Fundación Caja de Arquitectos.

UTZON, J. et al. (2010). Jørn Utzon: Conversaciones y Otros Escritos. Barcelona: Gustavo Gili.

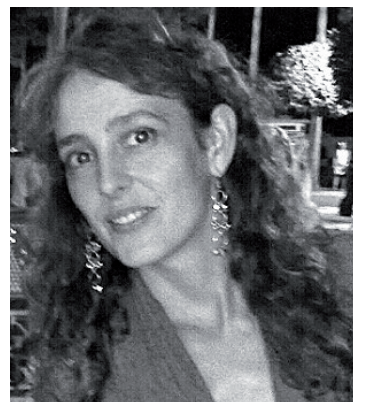

\section{Carmen García Sánchez}

arquitectocarmen@gmail.com

Ph. D. Carmen García Sánchez studied architecture at the Escuela Técnica Superior de Arquitectura, Polytechnic University of Madrid, where she defended her doctoral thesis titled "1950 en torno al Museo Louisiana 1970" (1950 around Louisiana Museum 1970), that was rated A Cum Laude. It analyzes several buildings that were built in Denmark in the 50's and 60's. Parallel, as a licensed architect, she works to develop architectural design projects at her office. C/López de Hoyos 155, 1p.2 Madrid 28002 Spain. 